\title{
Perkembangan Wakaf Asuransi Syariah di Indonesia Pasca Terbitnya Fatwa DSN-MUI No. 106 Tahun 2016
}

\author{
Muh. Luthfi Hakim \\ Institut Pesantren Mathali'ul Falah Pati \\ hakim@ipmafa.ac.id \\ Siti Asiyah \\ Institut Pesantren Mathali'ul Falah Pati \\ sitiasivah@ipmafa.ac.id
}

\begin{abstract}
This research aims to explain how the development and potential of W aqf of Islamic insurance in Indonesia after published the fatwa by DSN-MUI in 2016 concerning the Waqf of insurance benefits and investment benefits in Islamic life insurance. This study uses a qualitative approach and use documentation methods as a data collection technique. All data will be analyzed by describing and making a general sense of the all data about the development of Waqf of Islamic insurance. The results of this research show that Waqf of Islamic insurance developed positively and has potential in the next future with a provision of conceptual and concrete constraints that can impede the development of $W$ aqf of Islamic insurance can be responded to by the management of $W$ aqf and public in general.
\end{abstract}

Keywords: Development of Waqf; W aqf of Islamic Insurance; DSN-MUI Fatwa.

\begin{abstract}
Abstrak
Tulisan ini bermaksud menjelaskan bagaimana perkembangan dan potensi wakaf asuransi syariah di Indonesia setelah diterbitkan fatwa DSN-MUI pada tabun 2016 tentang Wakaf Manfaat Asuransi dan Manfaat Investasi pada Asuransi Jiwa Syariah. Penelitian ini menggunakan pendekatan kualitatif dengan metode dokumentasi sebagai teknik pengumpulan data yang digunakan. Data-data yang terkumpul dianalisa dengan cara mendeskripsikan dan membuat gambaran menyelurub (general sense) terhadap keseluruban data yang berkaitan dengan perkembangan wakaf asuransi syariah. Hasil penelitian ini menunjuk.kan babwa wakaf asuransi syariah berkembang dengan positif dan memiliki potensi besar di masa depan dengan catatan kendala-kendala konseptual maupun konkret yang dapat menghambat laju perkembangan wakaf asuransi syariah dapat direspon secara baik oleh pengelola wakaf dan masyarakat secara umum.
\end{abstract}

Kata Kunci: Perkembangan Wakaf; Wakaf Asuransi Syariab; Fatwa DSN-MUI.

\section{A. Pendahuluan}

Sebagai salah satu jenis filantropi Islam, pada masa kejayaannya wakaf memiliki pengaruh besar terhadap pertumbuhan dan kemajuan ekonomi umat Islam. Sejarah mencatat pada abad ke-8 dan ke-9 Hijriah, lembaga wakaf yang 
Perkembangan Wakaf Asuransi Syariah...

dikelola oleh Sultan dan Amir berada pada puncak kejayaannya. Pengelolaan yang profesional menjadi kunci utama pencapaian jumlah aset wakaf yang sangat besar. Pencapaian inilah yang kemudian dapat didistribusikan kepada masyarakat untuk meningkatkan kesejahteraan dalam bidang ekonomi. ${ }^{1}$

Setelah melewati era keemasaan di atas, lembaga wakaf terus mengalami kemunduran dari masa ke masa. Sadar akan begitu pentingnya peran yang diberikan, sejumlah negara berpenduduk (mayoritas) muslim di belahan dunia ingin kembali mengulang torehan "tinta emas" yang pernah dicapai oleh lembaga wakaf. Indonesia tidak diam begitu saja, merespon hal tersebut Indonesia menerbitkan Undang-Undang Nomor 41 tahun 2004 tentang wakaf sebagai legalitas lembaga perwakafan. Undang-Undang ini merupakan penyempurna bagiregulasi-regulasi yang telah ada sebelumnya, yaitu Peraturan Pemerintah Nomor 28 tahun 1977 tentang Perwakafan Tanah Milik, Instruksi Presiden Nomor 1 tahun 1991 tentang Kompilasi Hukum Islam yang termuat dalam Buku III (Hukum Perwakafan).

Terlepas dari pro-kontra yang berkembang, kebijakan pemerintah Indonesia untuk menyempurnakan regulasi wakaf melalui Undang-Undang Nomor 41 Tahun 2004 membawa nuansa baru terhadap praktik wakaf yang ada, termasuk di dalamnya disebutkan peraturan wakaf uang (cash waqf) yang memungkinkan pengelolaan wakaf secara produktif dengan menjaga nilai aset wakaf dan mendistribusikan hasilnya sebagai upaya perwujudan kesejahteraan umum.

Berkembangnya konsep wakaf uang dan wakaf produktif lainnya, melahirkan modifikasi-modifikasi baru di bidang perwakafan, termasuk yang sedang menjadi fokus penelitian ini yaitu wakaf dalam bentuk asuransi syariah. Wakaf model ini mulai beroperasi bersamaan dengan lahirnya fatwa DSN-MUI No: 106/DSN-MUI/X/2016 tentang Wakaf Manfaat Asuransi dan Manfaat Investasi pada Asuransi Jiwa Syariah. Wakaf asuransi syariah atau yang dikenal

${ }^{1}$ Ulya Kencana, Hukum Wakaf Indonesia, Sejarah, Landasan Hukum Dan Perbandingan Antara Hukum Barat, Adat Dan Islam (Malang : Setara Press, 2017). 
dengan wakaf manfaat asuransi syariah memunculkan daya tarik tersendiri dan potensial pada era sekarang mengingat kemudahanyang ditawarkan oleh wakaf ini dapat diterapkan oleh siapa pun. Sejalan dengan hal tersebut, ketua BWI menyatakan bahwa strategi pengelolaan wakaf ke depan adalah investasi, wakaf jenis ini dapat menjadi problem solving perekonomian umat. ${ }^{2}$

Namun di sisi lain, keberadaan regulasi wakaf secara umum maupun lebih spesifik wakaf asuransi syariah belum menampakkan hasil signifikan berdasarkan potensi yang dimiliki dengan realisasinya. Sebagai contoh, Luas tanah wakaf di Indonesia (memiliki sertifikat tanah wakaf dari BPN) mencapai 111.481.173 $\mathrm{M}^{2},{ }^{3}$ belum mampu dimaksimalkan secara baik. Begitu juga dengan wakaf uang, potensinya setiap tahun yang mencapai Rp. 3 triliun hanya mampu dihimpun dan dikelola sebesar Rp. 400 miliar oleh Badan Wakaf Indonesia. ${ }^{4}$

Sama halnya dengan potensi wakaf uang, wakaf asuransi syariah juga dinilai memiliki masa depan cerah dalam rangka menggali potensi wakaf yang belum sesuai dengan ekspektasi wakaf saat ini. Setidaknya jika dilihat dari faktor perkembangan industri keuangan asuransi syariah yang berkembang saat ini dapat memberikan gambaran hipotesis awal bahwa wakaf sebagai produk asuransi syariah akan berjalan seirama dengan tumbuh berkembangnya perusahaan asuransi syariah itu sendiri. Tulisan ini bermaksud mengekplorasi lebih jauh tentang perkembangan wakaf asuransi syariah dan menjelaskan kemungkinan potensi yang dapat dicapai melalui sinergi wakaf dan perusahaan asuransi syariah.

\section{B. Metode Penelitian}

Penelitian ini berusaha mengekplorasi dan memahami bagaimana perkembangan dan potensi wakaf asuransi syariah dengan dengan mengacu pada besarnya potensi industri asuransi syariah saat ini. Menggunakan pendekatan kualitatif ${ }^{5}$, tulisan ini akan mendeskripsikan persoalan wakaf asuransi syariah

2"Badan Wakaf Indonesia."

3"Badan Wakaf Indonesia."

4Khadijah Hasim, Deni Lubis, and Khalifah Muhammad Ali, 'Analisis Faktor-Faktor Yang Memengaruhi Penghimpunan Wakaf Uang Di Indonesia (Pendekatan Analytical Network Process)', Jurnal Al-Muzara'ah Vol.4, No.2, 2016, 4.2 (2016).

5 John W. Creswell, Research Design Pendekatan Metode Kualitatif, Kuantitafif, Dan Campuran (Yogyakarta: Pustaka Pelajar, 2019). 
Perkembangan Wakaf Asuransi Syariah...

secara komprehensif dan menafsirkannya untuk kemudian menarik kesimpulan dan hasil penelitian.

Metode dokumentasi ${ }^{6}$ digunakan sebagai teknik pengumpulan data dalam penelitian ini. Dokumen-dokumen dimaksud berupa data-data yang memuat permasalahan wakaf asuransi syariah, yang terfokus pada peluang serta potensinya ke depan dalam dunia filantropi Islam di Indonesia.

Selanjutnya teknik analisis data dilakukan dengan cara mendeskripsikan dan membuat gambaran menyeluruh (general sense) ${ }^{7}$ atas keseluruhan data yang diperoleh berkaitan dengan wakaf dan asuransi syariah, menganalisa data-data tersebut secara induktif, serta melakukan interpretasi atau pemaknaan data berupa kesimpulan yg diperoleh berdasarkan perbandingan antara hasil penelitian dengan informasi yg bersumber dari literatur yang berbicara mengenai wakaf dan asuransi syariah. Dengan demikian dalam penelitian ini akan ditemukan kesimpulan yang menggambarkan perkembangan dan potensi yang dimiliki oleh wakaf asuransi syariah.

\section{Perkembangan Wakaf}

Sebelum sampai pada pokok pembahasan potensi wakaf asuransi syariah, terlebih dahulu dipaparkan gambaran umum wakaf dan asuransi syariah. Wakaf dalam kajian hukum Islam berasal dari bahasa Arab al-waqf yang merupakan mashdar dari kata waqafa-yaqifu-waqfan. Secara bahasa wakaf diartikan sebagai alhabs (menahan), bentuk mashdar dari habasa-yahbisu-habsan. Fuqaha mengartikan wakaf dengan menahan harta tertentu yang bisa dipindah milikkan, mungkin untuk dimanfaatkan tanpa mengurangi fisiknya, dan memutus hak tasharruf pada harta tersebut karena ditujukan untuk ditasharrkan di jalan kebaikan dengan tujuan mendekatkan diri kepada Allah. Penggunaan kata al-waqf dibatasi pada obyek tertentu berupa benda wakaf, sehingga kata al-waqf memiliki kesamaan arti dengan al-habs. Mausu'ah Fiqh Umar Ibn Khottab mendefinisikan kata al-waqf dengan menahan asal harta dan menjalankan hasilnya.

\footnotetext{
${ }^{6}$ Arikunto Suharsimi, "Prosedur Penelitian : Suatu Pendekatan Praktik (Edisi Revisi)," Jakarta: Rineka Cipta (2013).

${ }^{7}$ Creswell, Research Design Pendekatan Metode Kualitatif, Kuantitafif, Dan Campuran.
} 
Dalam hal ini, Kompilasi Hukum Islam pasal 215 ayat (1) mendefinisikan wakaf sebagai "perbuatan hukum seseorang atau kelompok orang atau badan hukum yang memisahkan sebagian dari benda miliknya dan melembagakannya untuk selama-lamanya guna kepentingan ibadat atau kerpeluan umum lainnya sesuai dengan ajaran Islam”. Tidak jauh berbeda, Hukum Wakaf Indonesia dalam Undang-undang Nomor 41 Tahun 2004 menjelaskan dalam pasal 1 ayat (1) bahwa "Wakaf adalah perbuatan hukum wakif untuk memisahkan dan/atau menyerahkan sebagian harta benda miliknya untuk dimanfaatkan selamanya atau untuk jangka waktu tertentu sesuai dengan kepentingannya guna keperluan ibadah dan/atau kesejahteraan umum menurut syariah".

Wakaf merupakan salah satu filantropi Islam yang berbentuk aktiva tetap, misalnya wakaf tanah dan bangunan yang diperuntukkan sebagai pengembangan lembaga pendidikan, masjid, serta lembaga sosial-keagamaan yang lain. Pada perkembangannya, wakaf yang semula hanya terbatas pada benda-benda tidak bergerak, kemudian mengalami modifikasi dengan munculnya konsep wakaf tunai “cash waqf” sebagaimana yang terjadi pada masa khalifah Utsmaniyyah.

Berbeda dengan filantropi Islam lainnya (seperti Zakat, dsb), wakaf memiliki syarat-rukun yang terbilang ketat. Wakaf dianggap sah (boleh) apabila memenuhi ketentuan-ketentuan berikut. Pertama, mauquf (harta yang diwakafkan) adalah berupa barang yang dapat dimanfaatkan tanpa mengurangi fisik barang tersebut, dan kemanfaatan diperbolehkan oleh syara'. Kedua, wakaf harus diperuntukan pada asal (mauquf alaih pertama) yang ada dan far' (mauquf alaih berikutnya) yang tidak akan terputus. Ketiga, wakaf tidak dilakukan pada hal-hal yang tidak diperbolehkan oleh Islam. Tidak berhenti di sana, akad wakaf juga menghendaki terpenuhinya 4 (empat) rukun. Pertama, orang yang berwakaf (waqif). Kedua, benda yang diwakafkan (mauquf). Ketiga, ikrar wakaf atau dikenal dengan istilah sighat wakaf. Keempat, orang yang menerima manfaat/peruntukan wakaf (mauquf 'alaih).

Bentuk wakaf dalam praktik perwakafan pada periode awal Islam telah dikenal dua jenis wakaf, yaitu wakaf yang diperuntukkan untuk orang-orang 
Perkembangan Wakaf Asuransi Syariah...

tertentu saja dan wakaf untuk umum. Wakaf yang disebutkan pertama dalam istilah fiqh disebut dengan wakaf ahly, misalnya wakaf yang diperuntukkan untuk para cucu atau untuk kerabat. Asal mula wakaf ahly adalah peristiwa wakaf yang dilakukan oleh sahabat Abu Talhah dengan dengan petunjuk Rasulullah, Abu Talhah memberikan sebidang tanah untuk diwakafkan kepada kerabatnya. Berbeda dengan wakaf ahly, wakaf yang diperuntukkan untuk umum dikenal dengan sebutan wakaf khoiry. Contoh wakaf khoiry adalah yang pernah dipraktikkan salah seorang sahabat dari Bani Ghifar. Sahabat tersebut mewakafkan sebuah mata air (mata air rawmah) untuk keperluan kaum muslim secara umum. Pada dasarnya kedua bentuk wakaf ini tidak berbeda kecuali dalam hal peruntukannya, wakaf ahly diperuntukkan bagi orang-orang tertentu, sementara wakaf khoiry diperuntukkan bagi umum.

Melihat kedua jenis wakaf di atas, maka wakaf khoiry yang diperuntukkan untuk kemaslahatan bersama memberikan keleluasaan bagi pengelola wakaf untuk mengembangkannya, baik dalam bentuk investasi atau usaha-usaha lainnya yang sejalan dengan prinsip Islam.

\section{D.Asuransi Syariah dan Wakaf Asuransi Syariah}

Kemunculan wakaf tunai memberikan peluang bagi setiap orang dari segala lapisan masyarakat dapat mewakafkan harta bendanya tanpa harus menunggu memiliki sebidang tanah atau bangunan. Demikian halnya, wakaf tunai secara tidak langsung menjadi pembuka bagi munculnya model-model lain di bidang perwakafan, salah satunya wakaf manfaat asuransi syariah. Wakaf yang disebutkan belakangan masih belum banyak dikenal oleh masyarakat muslim di Indonesia.

Berbeda dengan wakaf yang sudah dikenal pada masa Nabi Muhammad, dalam sejarah tidak ditemukan literasi yang membuktikan adanya asuransi pada masa Nabi, sahabat, dan bahkan era tabi'in. Mengutip apa yang ditulis oleh Arif Effendi, dijelaskan bahwa asuransi baru ada sekitar tahun 1182 M. Kemunculan konsep yang mirip dengan asuransi tersebut dilatarbelakangi oleh pengusiran negara Perancis terhadap orang-orang Yahudi untuk menjamin resiko barang- 
barang bawaan mereka yang diangkut melalui jalur laut. Pada tahun $1680 \mathrm{M}$ di London diadakan lembaga asuransi kebakaran sebagai imbas kebakaran pada tahun 1666 yang telah menghanguskan sekitar 13.000 rumah dan 100 buah gereja. ${ }^{8}$ Istilah asuransi adalah saduran yang diambil dari berbagai bahasa yakni bahasa Inggris assurance yang berarti jaminan, bahasa Italia insurensi yang berarti jaminan dan dari bahasa Belanda assurantie yang memiliki arti pertanggungan. Sedangkan dalam bahasa Arab kata asuransi dikenal dengan tiga sebutan yakni at-ta'min (ketenangan, rasa aman, perlindungan dan bebas dari rasa takut), at-takaful (menjamin atau saling menanggung) dan tadhamun (saling menanggung). ${ }^{9}$ Asuransi-asuransi di atas masih bersifat konvensional dan belum menggunakan konsep asuransi syariah sebagaimana yang kita pahami saat ini.

Asuransi syariah mempunyai kesamaan dengan beberapa akad dalam bahasa Arab, yaitu takaaful, ta'mün dan tadlaamun yang berarti saling menolong dan menanggung. Istilah ini selaras dengan pengertian yang dipaparkan oleh Majelis Ulama Indonesia dalam Fatwanya Nomor 21/DSN-MUI/X/2001, di sana disebutkan bahwa Asuransi Syariah (Ta'min, Takaful, atau Tadhamun) adalah "usaha saling melindungi dan tolong-menolong di antara sejumlah orang/pihak melalui investasi dalam bentuk aset dan/atau Tabarru'yang memberikan pola pengembalian untuk menghadapi risiko tertentu melalui akad (perikatan) yang sesuai dengan syariat Islam". ${ }^{10}$ Istilah Syariah mengantarkan pada pemahaman yang berbeda dengan asuransi konvensional. Instrumen dalam asuransi syariah mengacu pada penanaman modal pada perusahaan atau lembaga yang bebas dari hal-hal yang dilarang oleh Islam. Definisi tersebut mengindikasikan adanya prinsip dasar ekonomi Islam yang mengarah pada upaya untuk menolong satu sama lain dalam bingkai kemaslahatan bersama sebagai hamba Allah.

${ }^{8}$ Afif Effendi, “ASURANSI SYARIAH DI INDONESIA (Studi Tentang Peluang Ke Depan Industri Asuransi Syariah)," Wahana Akademika: Jurnal Studi Islam dan Sosial 3, no. 2 (2016). ${ }^{9}$ Muhammad Syakir Sula, Asuransi Syariah (Life and General) Konsep Dan Sistem Operasional (Jakarta: Gema Insani Press, 2004).

${ }^{10}$ Dewan Syariah Nasional MUI, 'Fatwa DSN-MUI No.21/DSN-MUI/X/2001 Tentang Pedoman Umum Asuransi Syariah', 2001. 
Perkembangan Wakaf Asuransi Syariah...

Konsep asuransi syariah sendiri mengacu pada konsep maslahah mursalah, dimana terdapat dua pihak yang melakukan interaksi sosial, satu pihak berperan sebagai penolong dan pihak lainnya sebagai pihak tertolong. Proses interkasi ini penting karena setiap individu memperoleh jaminan dan perlindungan baik jiwa maupun harta bendanya. ${ }^{11}$

Asuransi syariah menjadi “pengganti” terhadap sistem konvensional yang dalam praktiknya menggunakan akad pertukaran yang tidak sesuai dengan konsep Islam. Pola yang diterapkan asuransi syariah mendorong kepada setiap peserta untuk saling membantu dan tolong menolong satu sama lain dengan mengalokasikan sebagian dana asuransinya dalam bentuk tabarru' (untuk kebaikan bersama/kebajikan). Dana tabarru' tersebut akan disalurkan untuk siapa pun diantara peserta asuransi yang mendapat risiko (musibah) secara tidak terduga. Definisi ini menarik pada satu kesimpulan bahwa akad dalam asuransi syariah adalah akad untuk saling menolong (takafuli), bukan akad pertukaran. ${ }^{12}$

Pada praktiknya, dana iuran premi yang terhimpun dari semua peserta akan dikelola oleh perusahaan asuransi syariah untuk diinvestasikan sesuai dengan prinsipprinsip syariah. Prinsip syariah dimaksud adalah akad (investasi) yang di dalamnya tidak mengandung unsur penipuan (gharar), perjudian (maysir), riba, penganiayaan (dhulm), suap (risywah), investasi pada barang haram, dan untuk tujuan maksiat. Prinsip-prinsip inilah yang membuatnya berbeda dengan sistem asuransi konvensional. ${ }^{13}$

Sama halnya seperti asuransi secara umum, asuransi syariah juga terbagi ke dalam dua jenis, pertama asuransi keluarga/jiwa dan kedua dikenal dengan istilah asuransi umum. Terdapat konsep yang hampir sama antara jenis asuransi syariah dengan jenis wakaf yang terdiri dari wakaf ably dan wakaf khoiry. Tidak hanya terbatas pada kemirirpan jenis, keduanya juga mempunyai tujuan (ghayah) yang serupa. Wakaf dan asuransi syariah sama-sama bertujuan untuk saling tolong dan

${ }^{11 Z a i n u d d i n ~ A l i, ~ H u k u m ~ A s u r a n s i ~ S y r a i a h ~(J a k a r t a: ~ S i n a r ~ G r a f i k a, ~ 2016) . ~}$

${ }^{12} \mathrm{Ali}$, Hukum Asuransi Syraiah

13Dewan Syariah Nasional MUI, "Fatwa DSN-MUI No.21/DSN-MUI/X/2001 Tentang Pedoman Umum Asuransi Syariah.” 
membantu meringankan beban sesama hamba Allah untuk mencapai kemaslahatan umum. Namun, keduanya sudah pasti memiliki aturan main berbeda dalam hal syarat, rukun, dan mekanisme operasional. ${ }^{14}$

Perbedaan dalam hal ketentuan syarat dan rukun tidak serta merta menghalangi keduanya saling berkolaborasi untuk mencapai tujuan yang "sama". Pada konteks ini, lembaga asuransi syariah dapat menempati peran sebagai penerima sekaligus pengelola wakaf uang sebagaimana bank-bank syariah (LKSPWU). Baik bank syariah maupun asuransi syariah mengemban tanggung jawab yang sama agar bersinergi dengan nadzir untuk menerima wakaf uang sebagaimana yang diharapkan oleh Negara melalui Undang-undang. ${ }^{15}$

Terdapat tiga model konsep wakaf dalam asuransi syariah. Pertama, wakaf sebagai model asuransi. Wakaf sebagai model asuransi merupakan wakaf yang menjadikan tabarrifund yang ada pada asuransi syariah sebagai dana wakaf. Salah satu praktiknya antara lain perusahaan membentuk dana wakaf sebelum peserta asuransi ber-tabbaru, selanjutnya dana tabarru tersebut dialokasikan ke dalam dana wakaf fund, bukan tabarru' fund. Kedua, ada model wakaf yang dikenal dengan wakaf polis. Manfaat Polis yang sudah dipegang oleh pemegang polis diwakafkan kepada nazhir wakaf. Model ketiga adalah wakaf sebagai fitur produk asuransi syariah. Wakaf sebagai produk adalah produk yang dibuat perusahaan asuransi syariah di mana manfaat investasi dan manfaat asuransi diniatkan untuk diwakafkan. ${ }^{16}$

Terbitnya fatwa DSN MUI Nomor 106/DSN-MUI/X/2016 tentang wakaf manfaat asuransi dan manfaat investasi pada asuransi jiwa syariah membawa lompatan baru bagi munculnya potensi-potensi wakaf di Indonesia. Namun sayangnya, lahirnya fatwa tersebut belum banyak diketahui dan belum dimanfaatkan secara maksimal. Minimnya pengetahuan masyarakat muslim Indonesia tentang adanya konsep wakaf yang berkolaborasi dengan asuransi syariah secara tidak langsung menjadi salah satu faktor yang mempengaruhi belum ada perkembangan signifikan pada akad wakaf asuransi syariah.

\footnotetext{
14"Badan Wakaf Indonesia."

15"Badan Wakaf Indonesia."

16"Badan Wakaf Indonesia."
} 
Perkembangan Wakaf Asuransi Syariah...

\section{E. Perkembangan Wakaf Asuransi Syariah di Indonesia}

Sebagai negara yang penduduknya mayoritas muslim, Indonesia memiliki potensi wakaf uang yang sangat besar. Menurut Rusydiana sebagaimana Nasution bahwa jumlah muslim dermawan di Indonesia diperkirakan sebanyak 20 juta umat dan mewakafkan hartanya dengan bentuk uang dengan nominal 1 juta pertahun, sehingga potensi wakaf uang yang terkumpul mencapai 20 Triliun. ${ }^{17}$

Perkembangan wakaf uang di Indonesia dan negara-negara muslim pada umumnya, menunjukkan pertumbuhan positif dalam beberapa tahun terakhir. Hal ini disebabkan salah satunya oleh adanya sifat fleksibel dalam arti bahwa orang tidak perlu menunggu memiliki sebidang tanah atau bangunan untuk diwakafkan. Konsep wakaf uang tersebut memungkinkan seseorang dengan nominal uang berapa pun dapat dengan mudah mengikrarkan wakaf. Kemudahan ini mulai berlaku sejak terbitnya legalitas wakaf uang. Hal ini secara tidak langsung berdampak pada modifikasi-modifikasi baru terhadap konsep wakaf uang tersebut, di antaranya adalah kemunculan wakaf asuransi syariah yang sedang penulis bahas dalam penelitian ini. Selain wakaf uang sebagai embrio bagi kemunculan wakaf asuransi syariah, pertumbuhan asuransi syariah dalam beberapa tahun ini juga akan mempengaruhi seberapa cepat wakaf asuransi syariah berkembang.

Industri keuangan syariah termasuk di dalamnya asuransi syariah di Indonesia berpotensi besar menjadi pesaing di tingkat global dalam bidang keuangan syariah. Peluang tersebut dapat dilihat dari beberapa hal berikut: Pertama, Indonesia dengan mayoritas muslim melebihi 230 juta jiwa ${ }^{18}$ menjadi potensi tersendiri bagi pertumbuhan nasabah industri keuangan syariah; Kedua, peningkatan pertumbuhan ekonomi yang cukup baik di Indonesia, di mana ekonomi mengalami pertumbuhan cukup baik yaitu sekitar 6,0\%-6,5\%. Ketiga, perubahan sovereign credit rating Indonesia menjadi investment grade dapat menjadi daya

17 Aam Rusydiana and Solihah Sari Rahayu, "Bagaimana Strategi Pengembangan Wakaf Tunai Di Indonesia?," Jurnal Ekonomi dan Bisnis Islam (Journal of Islamic Economics and Business) 5, no. 1 (2019).

${ }^{18 K N K S, ~ " M e n a n g k a p ~ P e l u a n g ~ T r e n ~ W a k a f ~ P r o d u k t i f, " ~ K o m i t e ~ N a s i o n a l ~ K e u a n g a n ~ S y a r i a h ~}$ (KNKS), no. 4 (2019), https://knks.go.id/storage/upload/1569306459-KNKS Edisi Keempat September. 
tarik bagi investor melakukan investasi di Industri keuangan domestik. Keempat, anugerah kekayaan sumber daya alam dapat dijadikan sebagai underlying transaksi industri keuangan syariah. ${ }^{19}$

Besarnya potensi asuransi syariah sebagaimana disebutkan di atas, tidak kemudian dapat ditarik kesimpulan bahwa potensi wakaf asuransi syariah juga besar, mengingat ia hanya bagian kecil dari perjalanan pertumbuhan wakaf asuransi syariah. Potensi wakaf asuransi syariah di Indonesaia dapat dipetakan setelah ditemukan peluang dan juga tantangan yang dihadapi dalam perjalanan wakaf sebagai produk dari asuransi syariah.

Sama seperti halnya wakaf uang, wakaf asuransi syari'ah juga berdampak pada mobilisasi dana dari masyarakat menjadi lebih fleksibel. ${ }^{20}$ Beberapa alasan yang menjadi kekuatan bagi perkembangan wakaf asuransi syariah adalah:

a. Waqif sebagai pemberi wakaf memeliki ruang lingkup (segmentasi) yang lebih luas jika dibanding dengan wakaf biasa.

b. Industri Asuransi syariah yang berkembang signifikan di Indonesia secara berangsur-angsur menjadikan wakaf sebagai produk di dalam industri asuransi syariah.

c. Jumlah penduduk Indonesia yang mayoritas muslim mencapai $87 \%$ atau sekitar 230 juta jiwa ${ }^{21}$ menjadi pasar yang menjajinkan dalam pengembangan wakaf asuransi syariah.

d. Berbagai kemudahan yang ditawarkan oleh perusahaan asuransi syariah kepada nasabah dengan produk wakaf akan memberikan daya tarik tersendiri bagi masyarakat muslim untuk berwakaf melalui perusahaan asuransi syariah.

Pemetaan potensi wakaf asuransi syariah tidak dapat dipisahkan dari potensi wakaf secara umum, terutama potensi wakaf uang. Jumlah penduduk Indonesia 268 juta jiwa, yang mayoritas beragama Islam (BPS, 2019) 22 merupakan aset luar

${ }^{19}$ Effendi, "ASURANSI SYARIAH DI INDONESIA (Studi Tentang Peluang Ke Depan Industri Asuransi Syariah)."

20"Badan Wakaf Indonesia."

${ }^{21}$ KNKS, "Menangkap Peluang Tren Wakaf Produktif."

22BPS, "Statistik Indonesia 2020 Statistical Yearbook of Indonesia 2020," Statistical Yearbook of Indonesia, no. April (2020). 
Perkembangan Wakaf Asuransi Syariah...

biasa dalam rangka penghimpunan dan pengembangan wakaf uang termasuk di dalamnya wakaf asuransi syariah. Melalui pengeloaan yang tepat, dana yang terkumpul akan sangat berpengaruh dan dapat dimanfaatkan untuk pemberdayaan dan kesejahteraan umat.

Perhitungan potensi wakaf harta bergerak berupa uang sangat beragam tergantung asumsi dan argumentasi yang digunakan. Pertama, berdasarkan data Susenas tahun 2014, yang memperkiran jumlah penduduk Muslim di Indonesia mencapai 197 juta jiwa dan tersebar di 33 provinsi. Kedua, didasarkan pada tingkat pendapatan penduduk, yang dibagi menjadi dua kelompok yaitu penduduk dengan pendapatan menengah dan penduduk dengan pendapatan tinggi, kemudian tingkat pendapatan inilah yang dijadikan dasar atas perhitungan wakaf harta bergerak berupa uang. Ketiga, potensi wakaf uang dihitutung dengan membedakan 3 asumsi, yaitu:

a) Rendah, yaitu penduduk yang berwakaf (wakif) diperkiran hanya sebesar 10 persen saja dari jumlah penduduk Muslim dengan wakaf senilai Rp. 10.000 per orang setiap bulan;

b) Moderat, yaitu wakif diperkirakan sebesar 25 persen dari jumlah penduduk Muslim dengan wakaf senilai Rp. 10.000 per orang setiap bulan;

c) Tinggi (optimis), wakif sebesar 50 persen dari jumlah penduduk Muslim dengan wakaf senilai Rp. 10.000 per orang setiap bulan.

Berdasarkan data di atas, dapat diketahui bahwa sekitar 98,89 persen potensi wakaf uang berasal dari penduduk Muslim dengan pendapatan menengah, sementara sisanya merupakan potensi wakaf uang dari penduduk Muslim yang memiliki penghasilan tinggi. Jika 10 persen saja setiap penduduk Muslim mengeluarkan wakaf uang setiap bulan senilai Rp10.000, maka akan terkumpul wakaf uang senilai Rp. 197,0 miliar dalam satu bulan atau sekitar Rp. 2,36 triliun setiap tahunnya. Apabila lebih dari 10 persen dari penduduk muslim yang mengeluarkan wakaf uang, maka potensinya akan semakin tinggi dan besar. ${ }^{23}$

${ }^{23}$ Muhammad Afdi Nizar, Pengembangan Wakaf Produktif di Indonesia: Potensi dan permasalahan, dalam "Penguatan Fundamental Sektor Keuangan dalam Mendukung Stabilitas Perekonomian" (Jakarta: Nagakusuma Media Kreatif, 2017). 
Selain memiliki keterkaitan dengan wakaf uang, wakaf asuransi syariah juga sangat bergantung pada instrumen asuransi syariah. Asuransi syariah sebagai perusahaan penyedia produk wakaf sekaligus menjadi pengelola dana wakaf yang terkumpul dalam rekening tabarru' peserta asuransi untuk diinvestasikan sesuai dengan prinsip-prinsip syariah sebagaimana dijelaskan di muka.

Perkembangan yang dimiliki oleh asuransi syariah selama 5-10 tahun terakhir, mengantarkan pada suatu kesimpulan bahwa perkembangan wakaf yang terintegrasi dengan perusahaan asuransi memiliki prospek dan potensi besar di tahun-tahun mendatang. Memang masih terlalu dini untuk menyimpulkan hal tersebut, mengingat wakaf yang terintegrasi dengan asuransi syariah baru diperkenalkan selama 4 tahun terakhir. Akan tetapi berpikir optimis merupakan pilihan tepat sebagai langkah awal mengembangkan wakaf sebagai produk yang dikelola oleh perusahaan asuransi syariah.

Dalam angka, perkembangan asuransi syariah di Indonesia mengalami peningkatan baik dari perusahaan asuransi maupun dari asuransi luar negeri yang hampir mayoritas memiliki produk asuransi syariah. Setidaknya pada tahun 2012 ada sejumlah 46 perusahaan asuransi dan reasuransi syariah. Total premi asuransi syariah juga menunjukkan perkembangan yang positif di tengah market share kontribusi asuransi syariah yang hanya 3.96\% terhadap total asuransi. Jumlah tersebut terus mengalami peningkatan. ${ }^{24}$ Dewan Syariah Nasional (DSN) Majelis Ulama Indonesia (MUI) menyatakan hal yang sama, berdasarkan data Asuransi syariah, perusahaan Asuransi dan reasuransi syariah yang telah beroperasi telah mencapai lebih dari 40 perusahaan.

Terbitnya fatwa DSN-MUI No: 106/DSN-MUI/X/2016 tentang Wakaf Manfaat Asuransi dan Manfaat Investasi pada Asuransi Jiwa Syariah merupakan peluang yang dapat ditangkap oleh Badan Wakaf Indonesia mengembangkan wakaf uang melalui instrumen perusahaan asuransi syariah di samping wakaf uang yang sudah berjalan melalui LKS-PWU selama ini. Beberapa perusahaan asuransi yang sudah memiliki produk wakaf yang terintegrasi,di antaranya Takaful Keluarga

${ }^{24}$ Ahmad Rodoni, Asuransi Dan Pegadaian Syariah (Jakarta: Mitra Wacana Media, 2015). 
Perkembangan Wakaf Asuransi Syariah...

dengan produk Takafuling Salam Wakaf yang diluncurkan pada tahun 201725, Allianz yang menambahkan fitur Wakaf pada produk Asuransi Syariahnya ${ }^{26}$, dan yang terbaru adalah AXA Mandiri unit Syariah meluncurkan produk wakaf. ${ }^{27}$ Perusahaan-perusahaan asuransi tersebut merupakan sebagian dari sejumlah perusahaan asuransi di Indonesia yang memiliki produk wakaf, baik wakaf manfaat asuransi, maupun wakaf manfaat investasi.

Namun demikian, di samping peluang dan potensi yang dimiliki, wakaf asuransi syariah juga tidak lepas dari tantangan dan kekurangan. Menurut penulis beberapa tantangan tersebut di antaranya:

a. Sosialisasi yang kurang intensif menjadi penghambat bagi pertumbuhan penghimpunan dana wakaf di sektor tersebut.

b. Segmentasi wakaf asuransi syariah terbatas pada mayoritas waqif yang berdomisili di kota-kota besar, sementara waqif yang berada di kota kecil belum banyak yang menjadi peserta asuransi syariah, sehingga mereka belum mengenal wakaf model ini.

c. Tantangan klasik yang tidak kalah penting adalah kesadaran masyarakat untuk beralih dari berwakaf secara konvensional (wakaf tanah, dsb) ke model wakaf produktif, termasuk wakaf manfaat investasi asuransi syariah.

Sosialisasi inilah yang menjadi penyebab utama pemahaman masyarakat mengenai wakaf masih terbilang rendah. Berdasarkan laporan BWI, nilai Indeks Literasi Wakaf (ILW) secara Nasional baru mencapai skor 50,48\%. Angka tersebut dikategorikan rendah, terdiri dari Nilai Literasi Pemahaman Wakaf Dasar sebesar 57,67 dan Nilai Literasi Pemahaman Wakaf Lanjutan sebesar 37,97 yang berbicara tentang konsep wakaf produktif, wakaf uang, dan termasuk juga wakaf asuransi syariah. ${ }^{28}$

Sejumlah tantangan di atas akan menghambat perkembangan wakaf asuransi syariah yang memiliki potensi begitu besar. Apabila ketiga hambatan

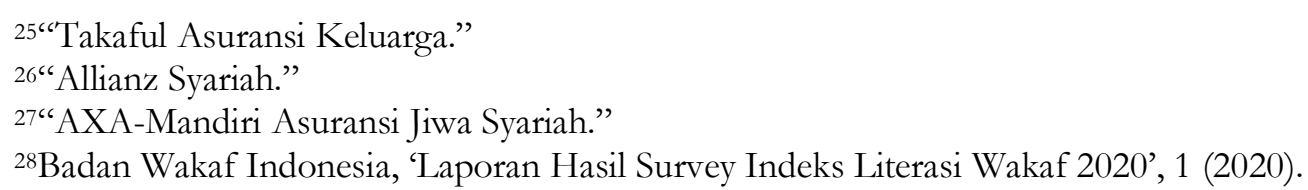


tersebut dapat diselesaikan dan dipetakan dengan baik, bukan tidak mungkin wakaf jenis ini akan memberikan kontribusi besar terhadap kesejahteraan umat di bidang pendidikan, ekonomi, kesehatan, dan infrastruktur negara.

Keberlangsungan wakaf asuransi syraiah juga dapat dipengaruhi oleh beberapa faktor yang menyebabkan wakaf secara umum belum mampu berkontribusi dalam program pemberdayaan umat. Pertama, pemahaman publik tentang hukum wakaf. Masyarakat belum banyak yang memahami hukum wakaf selain hanya terbatas pada wakaf tanah, wakaf bangunan untuk masjid, madrasah, dan sebagainya. Kedua, aspek internal manajemen wakaf belum sesuai dengan yang diharapkan dalam mengelola wakaf. Akibatnya, sejumlah harta benda wakaf banyak yang ditinggalkan, bahkan ada beberapa harta wakaf hilang. Ketiga, adanya pengawasan yang ketat terhadap lembaga pengelola wakaf untuk memastikan bahwa harta benda wakaf dikelola sebaik-baiknya dan seproduktif mungkin. ${ }^{29}$

\section{F. Kesimpulan}

Wakaf asuransi syariah merupakan salah satu satu model wakaf yang sedang berkembang dengan diperkuat oleh fatwa DSN MUI Nomor 106/DSNMUI/X/2016 tentang wakaf manfaat asuransi dan manfaat investasi pada asuransi jiwa syariah membawa lompatan baru bagi munculnya potensi-potensi wakaf di Indonesia. Akan tetapi di pihak lain, fatwa tersebut belum mampu memberikan daya dorong maksimal bagi pertumbuhan wakaf asuransi syariah. Melihat instrumen perkembangan asuransi syariah yang demikan pesat, harusnya dapat menjadi peluang besar terhadap pertumbuhan dan perkembangan wakaf melalui industri asuransi syariah untuk menyeimbangkan antara potensi yang ada dan realisasi di lapangan.

Beberapa permasalahan internal maupun eksternal yang perlu diselesaikan bersama guna meningkatkan realisasi potensi yang dimiliki wakaf asuransi syariah adalah dengan peningkatan intensitas sosialisasi kepada masyarakat mengenai konsep wakaf ini. Pasar peserta asuransi syariah yang terbatas pada masyarakat

${ }^{29}$ Abd. Kadir Arno, 'Wakaf Produktif Sebagai Instrumen Kesejahteran Sosial Dan Pemberdayaan Ekonomi Umat (Potensi Dan Tantangan)', Dinamis-Journal of Islamic Management And Bussines, 1.2 (2018). 
Perkembangan Wakaf Asuransi Syariah...

perkotaan menjadi kendala lain yang berdampak langsung bagi jumlah masyarakat yang berwakaf melalui perusahaan asuransi syariah. Di samping itu mindset publik untuk berpindah dari pola berwakaf secara konvensional ke arah wakaf produktif menjadi persoalan klasik yang masih menjadi kendala sampai saat ini.

\section{Daftar Pustaka}

Al-Bajury, Ibrahim. Haasyiyah Al-Bajury. Jakarta: Dar al-Kutub al-Islamiyah, 2007.

Al-Bantany, Imam An-Nawawi. Nihayat Al-Zain Fi Irsyad Al-Mubtadiin. Beirut: Dar alKutub al-Ilmiah, 2002.

Ali, Zainuddin. Hukum Asuransi Syraiah. Jakarta: Sinar Grafika, 2016.

Arno, Abd. Kadir. "WAKAF PRODUKTIF SEBAGAI INSTRUMEN KESEJAHTERAN SOSIAL DAN PEMBERDAYAAN EKONOMI UMAT (POTENSI DAN TANTANGAN)." DINAMIS- Journal of Islamic Management And Bussines 1, no. 2 (2018).

Badan Wakaf Indonesia. "Laporan Hasil Survey Indeks Literasi Wakaf 2020" 1 (2020): 7-8.

BPS. "Statistik Indonesia 2020 Statistical Yearbook of Indonesia 2020." Statistical Yearbook of Indonesia, no. April (2020): 192.

Creswell, John W. Research Design Pendekatan Metode Kualitatif, Kuantitafif, Dan Campuran. Yogyakarta: Pustaka Pelajar, 2019.

Dewan Syariah Nasional MUI. "Fatwa DSN-MUI No.21/DSN-MUI/X/2001 Tentang Pedoman Umum Asuransi Syariah" (2001): 1-7.

Effendi, Afif. "ASURANSI SYARIAH DI INDONESIA (Studi Tentang Peluang Ke Depan Industri Asuransi Syariah)." Wahana Akademika: Jurnal Studi Islam dan Sosial 3, no. 2 (2016): 71.

Haq, Ahmad Faishal. Hukum Perwakafan Di Indonesia. Jakarta: Rajawali Pers, 2017.

Hasim, Khadijah, Deni Lubis, and Khalifah Muhammad Ali. "Analysis of Factors Affecting The Level of Cash Waqf Raising in Indonesia (Analytical Network Process Approach) (Analisis Faktor-Faktor Yang Memengaruhi Penghimpunan Wakaf Uang Di Indonesia (Pendekatan Analytical Network Process))." Jurnal Al-Murara'ah Vol.4, No.2, 2016 4, no. 2 (2016): 127-141.

Kencana, Ulya. Hukum Wakaf Indonesia, Sejarah, Landasan Hukum Dan Perbandingan Antara Hukum Barat, Adat Dan Islam. Malang: Setara Press, 2017.

KNKS. "Menangkap Peluang Tren Wakaf Produktif." Komite Nasional Kenangan Syariah (KNKS), no. 4 (2019). https://knks.go.id/storage/upload/1569306459KNKS Edisi Keempat - September.pdf. 
Rodoni, Ahmad. Asuransi Dan Pegadaian Syariah. Jakarta: Mitra Wacana Media, 2015.

Rusydiana, Aam, and Solihah Sari Rahayu. "Bagaimana Strategi Pengembangan Wakaf Tunai Di Indonesia?” Jurnal Ekonomi dan Bisnis Islam (Journal of Islamic Economics and Business) 5, no. 1 (2019): 15.

Sabiq, Sayyid. Fiqh As-Sunnah. Beirut: Dar al-Fikr, 2008.

Suharsimi, Arikunto. "Prosedur Penelitian : Suatu Pendekatan Praktik (Edisi Revisi)." Jakarta: Rineka Cipta (2013).

Sula, Muhammad Syakir. Asuransi Syariah (Life and General) Konsep Dan Sistem Operasional. Jakarta: Gema Insani Press, 2004.

Syariah, Dewan, and Nasional Mui. "Fatwa Wakaf Manfaat Asuransi Dan Manfaat Investasi Pad a Asuransi Jiwa Syariah." Fatwa Dewan Syariah Nasional-Majelis Ulama Indonesia NO: 106/DS, no. 19 (2016): 6.

Zaenurrosyid, A. "Sengketa Wakaf Dan Penyelesaian Dalam Perspektif UndangUndang Wakaf No 41 Tahun 2004.” Journal Islamic Review, no. 41 (2013).

Zein, Satria Effendi M. Problematika Hukum Keluarga Islam Kontemporer. Jakarta: Kencana, 2010.

“Allianz Syariah.” https://www.allianz.co.id/produk/asuransi-syariah/fitur-wakaf.

“AXA-Mandiri Asuransi Jiwa Syariah.” https://www.axa-mandiri.co.id/axa-mandiriunit-syariah-ajak-nasabah-berwakaf-melalui-asuransi-jiwa-syariah/\#.

"Badan Wakaf Indonesia." https://www.bwi.go.id/4174/2019/12/berita/ketuabwi-jelaskan-potensi-wakaf-dalam-pembukaan-rakornas/.

"Badan Wakaf Indonesia." www.data.bwi.go.id/wakaf-tanah.

"Badan Wakaf Indonesia." https://www.bwi.go.id/529/2010/12/artikel/sinergiwakaf-dengan-instrumen-asuransi-syariah/.

"Badan Wakaf Indonesia." https://www.bwi.go.id/1531/2017/02/berita/beritawakaf/wakaf-manfaat-asuransi-ini-fatwa-dsn-mui/.

"Badan Wakaf Indonesia." https://www.bwi.go.id/783/2012/05/artikel/aplikasiwakaf-uang-di-indonesia.

"Takaful Asuransi Keluarga." https://takaful.co.id/2017/09/14/ajak-masyarakatuntuk-berasuransi-sambil-berwakaf-takaful-keluarga-luncurkan-takafulinksalam-wakaf/. 
Perkembangan Wakaf Asuransi Syariah... 